TITLE:

\title{
ON THE DISTRIBUTION OF CHAETOGNATHS IN THE WATERS OFF THE SOUTH-EASTERN COAST OF JAPAN (JEDS-3)
}

$\operatorname{AUTHOR}(S)$ :

Furuhashi, Kenzo

CITATION:

Furuhashi, Kenzo. ON THE DISTRIBUTION OF CHAETOGNATHS IN THE WATERS OFF THE SOUTH-EASTERN COAST OF JAPAN (JEDS-3). PUBLICATIONS OF THE SETO MARINE BIOLOGICAL LABORATORY 1961, 9(1): 17-30

\section{ISSUE DATE:}

1961-05-30

URL:

http://hdl.handle.net/2433/174665

RIGHT: 


\title{
ON THE DISTRIBUTION OF CHAETOGNATHS IN THE WATERS OFF THE SOUTH-EASTERN COAST OF JAPAN ${ }^{1,2)}\left(\right.$ JEDS-3) $^{-3}$
}

\author{
KENZŌ FURUHASHI \\ Kōbe Marine Observatory, Kōbe
}

With 11 Text-figures and 1 Table

\section{Introduction}

The difference found in the deep water copepod fauna between the areas west and east of the submarine ridge stretching southwards from the end of Izu Peninsula including the Ogasawara Islands on its way was discussed in the previous paper of the present author. In a hope to ascertain whether a similar difference can be seen in the chaetognath fauna or not, the data got from a large collection of chaetognaths made in the deep waters off the south-eastern coast of Japan are treated here in reference to the nature of the water masses west and east of the Ridge mentioned above.

Since 1954, many plankton samples have been collected from the subsurface waters of the Kuroshio region west of the Ridge by the Kobe Marine Observatory and the author examined those which came from the $0-100 \mathrm{~m}$ layer, some results obtained were already published in the previous paper (FURUHASHI, 1959). In addition to these, nine more collections were made by divided hauls in the layer from $2500 \mathrm{~m}$ to the surface in the same region in the years 1958-'60. And in the summer of 1957, the I. G. Y. Observations worked in the cold Oyashio region and the author had a chance to make two vertical hauls respectively from $600 \mathrm{~m}$ and $100 \mathrm{~m}$ to the surface. The results of the close examination on these samples together with those on the preceding collection made by the Kōbe Marine Observatory are embodied in the present paper.

The distinction between the deep water chaetognath faunas west and east of the Ridge does not seem so remarkable as in the case of copepods. However, the present work may be considered to be significant in that it shows roughly the outline of the vertical distribution of respective species in the Japanese waters, about which very little has been known.

1) JEDS Contribution No. 17.

2) Contribution from the Kobe Marine Observatory.

Publ. Seto Mar. Biol. Lab., IX (1), 1961. (Article 2) 
At the same time, the results here published together with the data obtained from the extensive observations made by the Kobe Marine Observatory show the differentiation of the chaetognath fauna found between the inshore and offshore waters off the Pacific coast of middle Japan, the exact feature about this have not yet been cleared, either.

Before going further, the author wishes to express his hearty thanks to Dr. Takasi Tokioka of the Seto Marine Biological Laboratory for his kind encouragement and very helpful advices given throughout the present work. $\mathrm{He}$ is also much indebted to the members of oceanographical section of the Kobe Marine Observatory and the crew of the R.M.S. "Shunpū Maru" for their assistance in collecting samples.

\section{Material and Method}

The present material consists of six collections made at stations whose positions are shown in Fig. 1 and in Table 1. In the area west of the Ridge, six vertical hauls were made at St. A from $2440 \mathrm{~m}$ to the surface by divided hauls using a closing net and a single vertical haul was made from $1040 \mathrm{~m}$ to $580 \mathrm{~m}$ with a closing net at St. B. Besides these, a single vertical haul was made at Sts. I4 and G4 respectively from $920 \mathrm{~m}$ and $1080 \mathrm{~m}$ to the surface with a closing

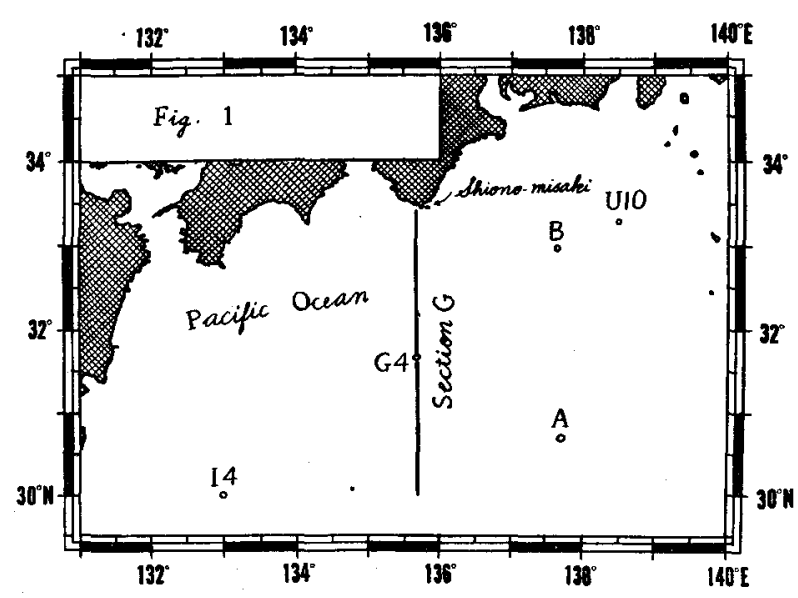

Fig. 1. Map showing the position of five stations and the Section $G$ in the area west of the Ridge surveyed by the Kōbe Marine Observatory. Readers may feel strange at that St. A in the Kuroshio area, while Stations I4 and G4 are in the far offshore water beyond the Current of Kuroshio. This is because the Kuroshio changes the course from time to time and the collections were made at respective station in different seasons of different years. 
Table 1. Occurrence of chaetognaths in respective samples collected at 7 stations in the sea off the south-eastern coast of Japan. (* from Matsudaira \& Furuhashi, 1955).

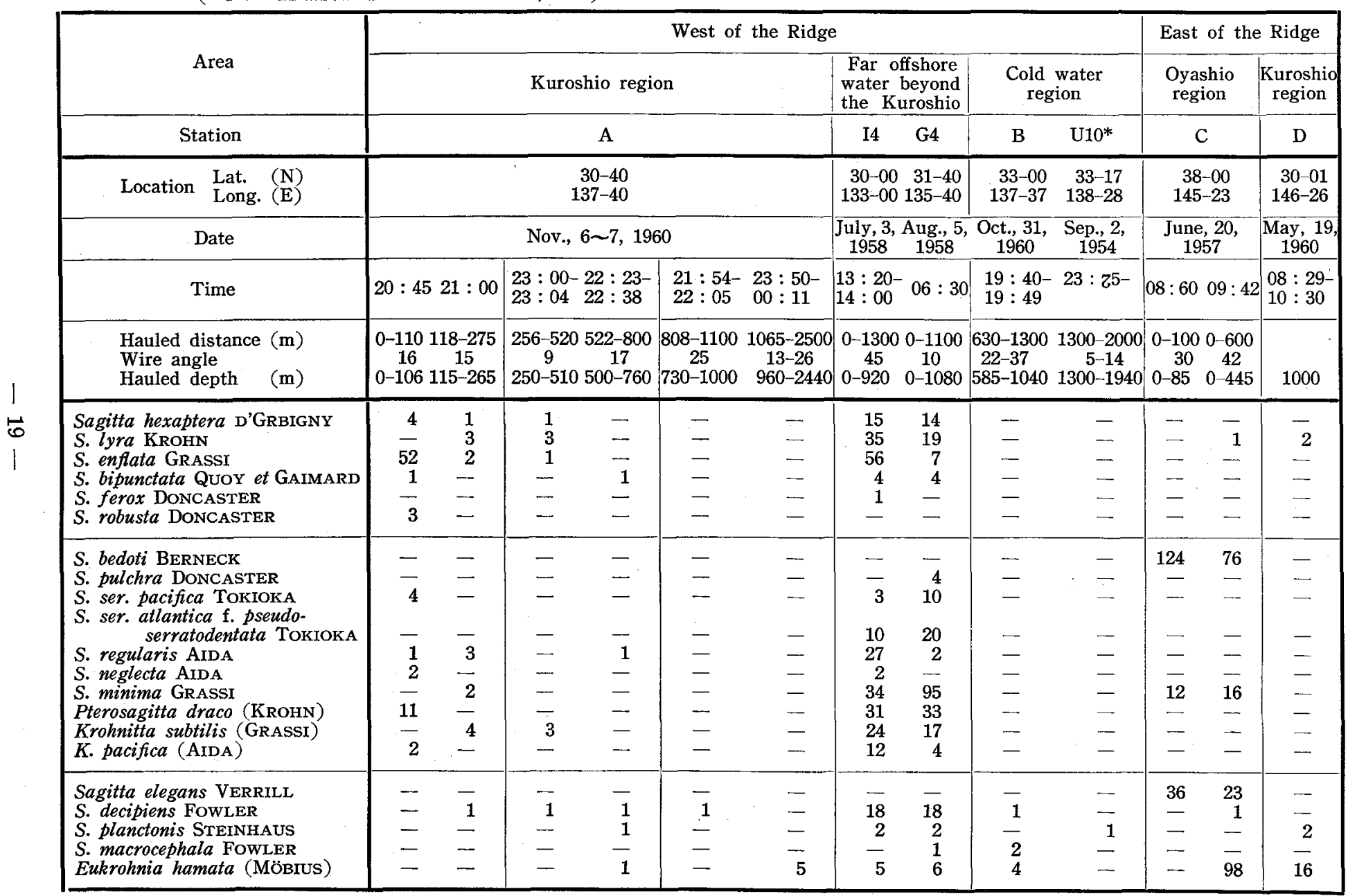


net. In the area east of the Ridge, two vertical hauls were made respectively from $600 \mathrm{~m}$ and $100 \mathrm{~m}$ to the surface at St. C with a quantitative plankton net. At St. D, horizontal towings were made at several layers by letting the ship drift for two hours during the JEDS-3 Cruise and one of these samples collected at the $1000 \mathrm{~m}$ layer was examined. The net used during the above-mentioned operations have a $51 \mathrm{~cm}$ mouth diameter and is stretched with the fine bolting silk (GG-54) having about $0.3 \mathrm{~mm}$ square meshes. The whole contents of every sample were examined and every specimen of chaetognaths was picked out to be identified and recorded. The raw data thus obtained are shown in Table 1.

\section{Distribution of Chaetognaths in Respective Areas}

\section{1) The Kuroshio region west of the Ridge}

In the samples collected at St. A, 15 species belonging to four genera were found. Nine of these species seemed to be warm-water species and were found only in the sample collected from $110 \mathrm{~m}$ to the surface, Sagitta enflata being the most abundant species of all. These nine species decreased in number with the depth and disappeared completely in samples collected at the level deeper than $730 \mathrm{~m}$. On the other hand, three other species were considered to be abyssal forms and found in the deep-water samples. Sagitta decipiens was a widely distributed species in the samples from $115 \mathrm{~m}$ to $1000 \mathrm{~m}$, though its occurrence was represented only by a single specimen. In the sample from the deepest layer only Eukrohnia hamata was found.

2) The far off shore waters beyond the Kuroshio region west of the Ridge

In samples collected at St. I4 and G4, 18 species belonging to four genera were found. Among these, Sagitta decipiens, S. planctonis, S. macrocephala and Eukrohnia hamata were considered to be abyssal forms. The compositions at these stations show that the proportion of Sagitta enflata to all other warmwater species is much less than that throughout the whole samples at St. A. It is $28 \%$ at St. I4 and $3 \%$ at St. G4, while it attains $106 \%$ at St. A.

The tendency of $S$. enflata towards the decrease was shown by Tokioka in the far oceanic water of the Central North Pacific (TokiokA, 1959), too.

3) The cold water region west of the Rdige

In the sample collected at St. B, there occurred only 3 species, Sagitta decipiens, S. macrocephala and Eukrohnia hamata. Besides, the occurrence of a single specimen of Sagitta planctonis in the sample collected from $1940 \mathrm{~m}$ to $1300 \mathrm{~m}$ at St. U10 in the same region is recorded (Matsudaira \& Furuhashi, 1955). Thus, the composition of chaetognath population in the deep water of the cold water region is quite the same as that in the deep water of the Kuroshio region west of the Ridge. 


\section{4) The Kuroshio region east of the Ridge}

In the sample collected at St. D, only three species were identified. Eukrohnia hamata was the most abundant species, while Sagitta lyra and S. planctonis were rather scarce. Though this composition resembles that found in the Kuroshio regions west of the Ridge, the proportion of Eukrohnia hamata seems to be much larger than in the Kuroshio region west of the Ridge.

\section{5) The Oyashio region}

Three species were found in the sample collected from $100 \mathrm{~m}$ to the surface at St. C and Sagitta bedoti was the most abundant species of all the three. On the other hand, 6 species were identified in the sample collected from $600 \mathrm{~m}$ to the surface and Eukrohnia hamata was the most abundant species of these. Sagitta elegans occurred commonly in both samples, but this species seems to occur seldom in the deeper water at this station.

\section{General Hydrographical Features in the Waters West of the Ridge}

Seventy-six vertical hauls from $100 \mathrm{~m}$ to the surface and a series of hydro-

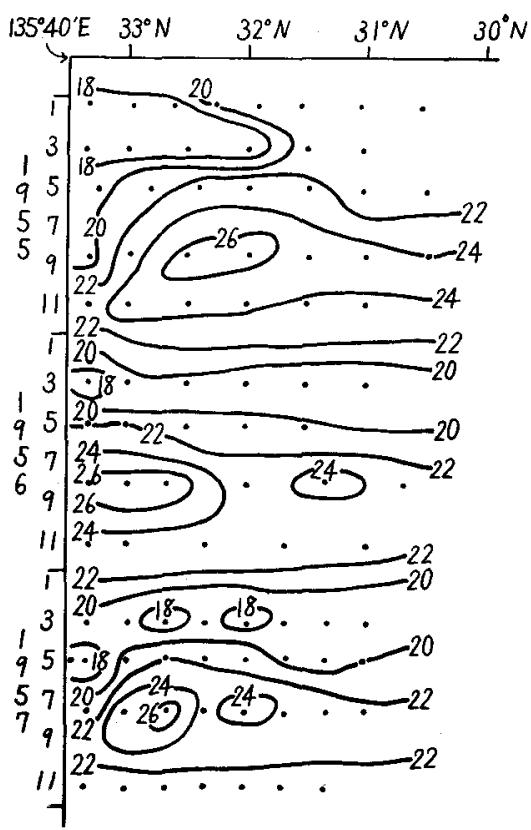

Fig. 2. The seasonal variation of the water temperature $\left({ }^{\circ} \mathrm{C}\right)$ at $50 \mathrm{~m}$ layer along Section $G$ south of the cape of Shionomisaki on the Pacific coast of middle Japan during the period from January, 1955 to November, 1957.

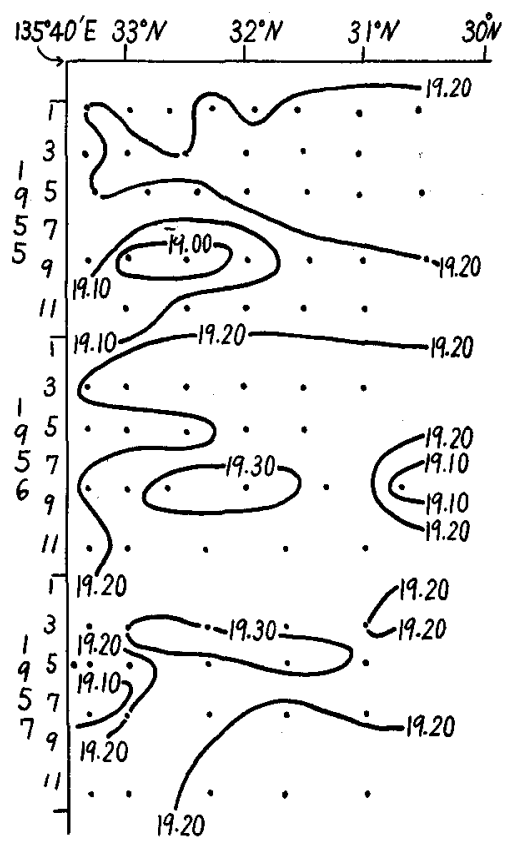

Fig. 3. The seasonal variation of the chlorinity (value in \%) at $50 \mathrm{~m}$ layer along Section $G$ south of the cape of Shionomisaki on the Pacific coast of middle Japan during the period from January, 1955 to November, 1957. 
graphical observations were made along Section $G$ in the waters south of the cape of Shionomisaki on the Pacific coast of middle Japan by the R.M.S. "Shunpū Maru" of the Kobe Marine Observatory during the period from January, 1955 to November, 1957. The seasonal variations of the water temperature and the chlorinity at $50 \mathrm{~m}$ layer along this section are shown respectively in Figures 2 and 3.

MORIYASU (1959) states that the cold water region was generally situated north of $32^{\circ} \mathrm{N}$ off the southern coast of middle Japan and with the westward extention in the beginnirg of 1955 , but the region was generally decayed and occasionally became quite obscure in 1956 . The cold water region is shown in Fig. 2 as the extensic $n$ of a low water temperature $\left(18^{\circ} \mathrm{C}\right)$ near the coast in the first half of 1955. Figures 2 and 3 show that the stream centre of the Kuroshio was far apart from the coast in that time, but it has approached to the coast since the summer of 1956.

\section{Distributional Aspects of Respective Species of Chaetognaths}

The occurrences of respective species of chaetognaths along Section $G$ during the years 1955 to 1957 are shown in Figures 411 which are considered to show the outline of the seasonal fluctuation of respective species of chaetognaths in the Kuroshio region west of the Ridge.

\section{1) Sagitta hexaptera}

The result of the statistical studies on many samples collected from $100 \mathrm{~m}$ to the surface in the waters off the Pacific coast of middle Japan reveals that this species occurs mainly in the far offshore water beyond the Kuroshio, but it is not found in the cold water region (FURUHASHI, 1959).

In the present material a few specimens occurred in the samples collected at the layers shallower than $510 \mathrm{~m}$ at St. A in the Kuroshio region west of the Ridge. More abundant specimens were caught in the far offshore water beyond the Kuroshio west of the Ridge (Station I4 and G4). The occurrence of the species along Section G south of the cape of Shionomisaki is shown

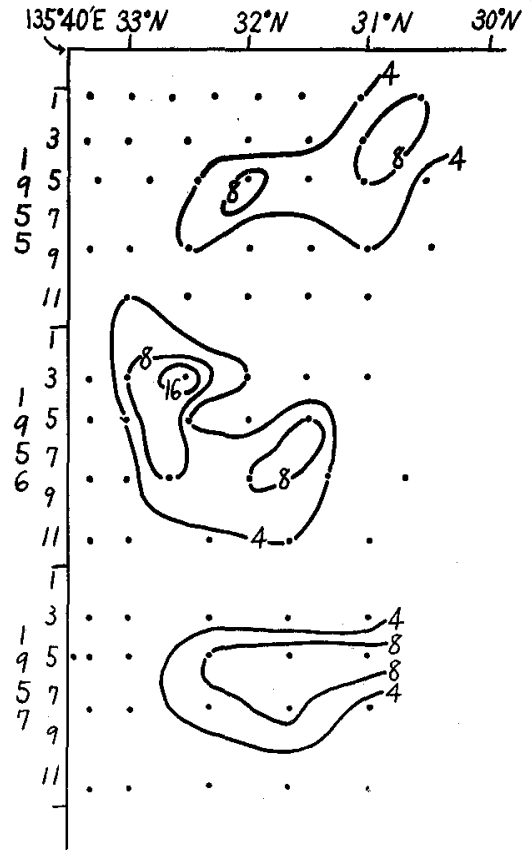

Fig. 4. Individual number of Sagitta hexaptera per $10 \mathrm{~m}^{3}$ along Section $G$ south of the cape of Shionomisaki on the Pacific coast of middle Japan during the period from January, 1955 to November, 1957. 
in Fig. 4 which shows that the seasonal fluctuation was not clear and the distribution seemed to be much affected by the strength of respective water masses found in the surveyed area.

\section{2) Sagitta lyra}

Three specimens were found in each of the samples respectively collected at the layers $250 \mathrm{~m}-510 \mathrm{~m}$ and $115 \mathrm{~m}-265 \mathrm{~m}$ at St. A, while abundant specimens were found in the samples collected at Stations I4 and G4 in the far offshore water of the Ridge. On the other hand, only a single specimen was found in one of the samples collected at St. C in the Oyashio region, this specimen was fully matured and $53 \mathrm{~mm}$ long, the maximum of all the specimens in this material.

The distribution of this species seems to trend towards the low water temperature, but this does not mean that the species is common in the cold water in the Pacific. In the surveyed area, this was abundant in the far offshore waters in both areas west and east of the Ridge. Figures 5 and 3 show that the chlorinity of the water of the distributional range of S. lyra off the southern coast of middle Japan was higher than $19.20 \%$.

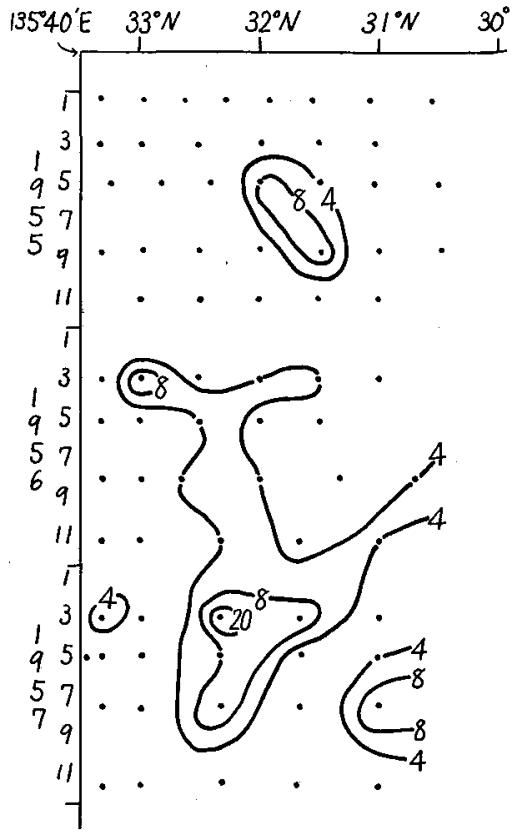

Fig. 5. Individual number of Sagitta lyra per $10 \mathrm{~m}^{3}$ along Section $\mathrm{G}$ south of the cape of Shionomisaki on the Pacific coast of middle Japan during the period from January, 1955 to Novem. ber, 1957.

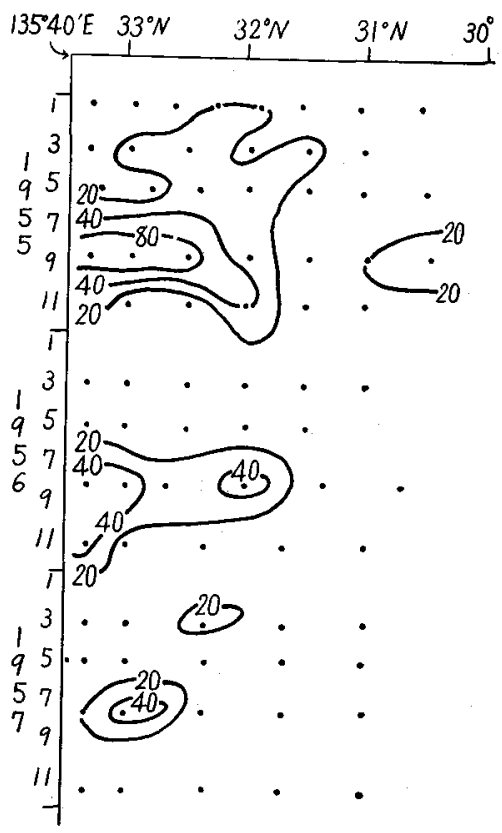

Fig. 6. Individual number of Sagitta enflata per $10 \mathrm{~m}^{3}$ along Section $\mathrm{G}$ south of the cape of Shionomisaki on the Pacific coast of middle Japan during the period from January, 1955 to November, 1957. 


\section{3) Sagitta enflata}

This is the commonest species in the Kuroshio region, occurring most abundantly in the subsurface water shallower than $510 \mathrm{~m}$ in the present observations. No individual occurred in the Oyashio region.

The occurrence of this species along Section $G$ was shown in Fig. 6, which shows that the species occurred most commonly in August and its maximal densities were observed in the area extending from the stream centre of the Kuroshio to the inshore waters, but the density decreased towards the offshore waters beyond the Kuroshio.

\section{4) Sagitta bipunctata, S. ferox, S. robusta \& S. pulchra}

These species are typical tropical water forms and occurred only sparsely in the samples collected in the Kuroshio region and in the far offshore waters west of the Ridge. None of these species were found in the Oyashio water samples.

\section{5) Sagitta bedoti}

The distributional feature of this species in the Indo-Pacific is reported by ToKioka (1959) who states that the water masses containing $S$. bedoti are reasonably separable from far oceanic water masses free from this species and proposes to call the former "bedoti-water" after this characteristic indicator. This seems to be applicable to the waters off the southern coast of middle Japan as is shown by the statistical study on the distribution of this species reported in the previous paper of the present author (Furuhashi, 1959).

The species also indicates clearly the existence of the cold water mass in the East China Sea (FuruhashI, 1958).

In the Japan Sea, this is the dominant species along the warm Tsushima current, but it decreases with the depth, being replaced by $S$. elegans, and quite disappears in the samples collected at layers deeper than $250 \mathrm{~m}$ (Furuhashi, 1953).

In the present material, this species was found commonly in samples collected in the Oyashio region, but quite missing in samples collected in the area west of

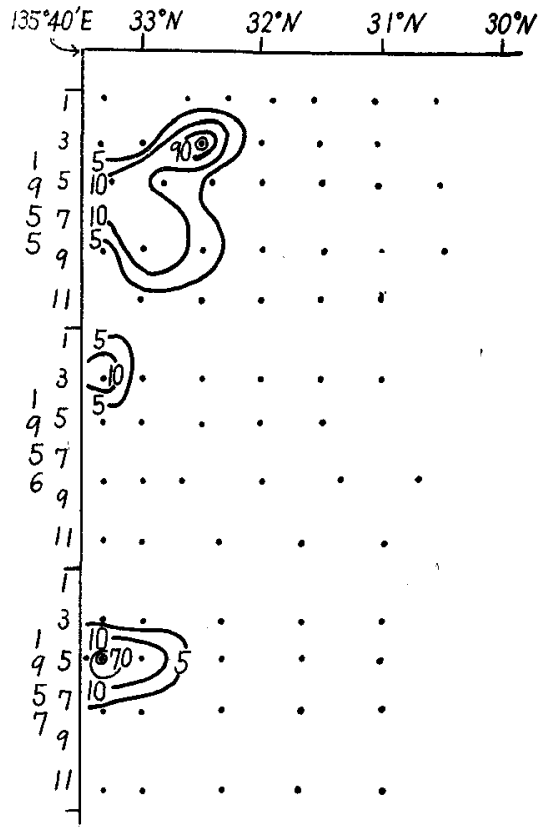

Fig. 7. Individual number of Sagitta bedoti per $10 \mathrm{~m}^{3}$ along Section G south of the cape of Shionomisaki on the Pacific coast of middle Japan during the period from January, 1955 to Novem. ber, 1957. 
the Ridge, even in those from the cold water region. At Stations B and U10 in the cold water region the collections were made respectively at the layers 1040-585 $\mathrm{m}$ and $1940-1300 \mathrm{~m}$. And the complete absence of $S$. bedoti in these deep water samples conforms well with that the distribution of this species is confined to the "bedoti-water" shallower than $250 \mathrm{~m}$ in the surveyed area.

The occurrence of this species along Section G is shown in Fig. 7, which, together with Figures 2 and 3, shows that $S$. bedoti occurs abundantly in the nearshore water in which the water temperature at $50 \mathrm{~m}$ layer is below $18^{\circ} \mathrm{C}$. This species was found in the samples collected at the offshore station in March, 1955 , when the cold water region was very extensive and the stream centre of the Kuroshio was maintained far off the coast.

\section{6) Sagitta serratodentata pacifica}

The commonest species in the shallow water samples of the Kuroshio region, although fully matured specimens were rather scarce in the present material as shown in Table 1. This species was not found in any samples collected in the Oyashio region and in any deeper water samples from the Kuroshio region, either.

7) Sagitta ser. atlantica f. pseudoser-

\section{ratodentata}

This species was not found in any samples from the Kuroshio region, but was rather common in the far offshore water samples.

\section{8) Sagitta regularia}

This species occurred in the samples collected from the waters shallower than $760 \mathrm{~m}$ in the Kuroshio region west of the Ridge. The occurrence of the species along Section $\mathrm{G}$ is shown in Fig. 8 which indicates the significant seasonal fluctuation of increasing in autumn.

\section{9) Sagitta minima}

Only two individuals were found in the single sample collected at the layer 265$115 \mathrm{~m}$ in the Kuroshio region west of the Ridge, but it occurred commonly in samples collected from $c a .1000 \mathrm{~m}$ to the surface in the far offshore water west of the Ridge and also in samples from the Oyashio region surveyed. This species seems to occur in

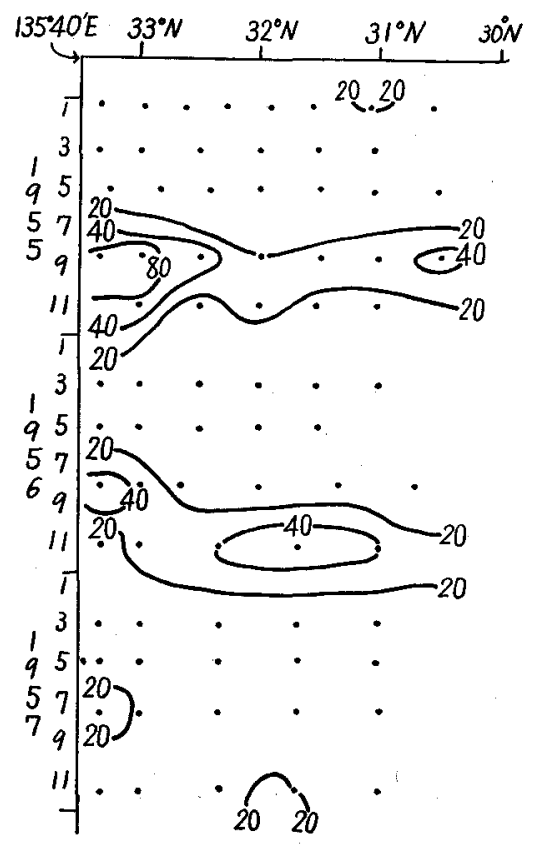

Fig. 8. Individual number of Sagitta regularis per $10 \mathrm{~m}^{3}$ along Section $G$ south of the cape of Shionomisaki on the Pacific coast of middle Japan during the period from January, 1955 to November, 1957. 
the water of rather low water temperatures as compared with other warm-water species.

The occurrence of this species along Section G is shown in Fig. 9. This shows that the occurrence seemed to avoid the winter season, while abundant occurrences were seen when the water temperature at $50 \mathrm{~m}$ layer was in the range from $20^{\circ} \mathrm{C}$ to $24^{\circ} \mathrm{C}$.

BIERI (1959) states that S. minima to inhabit the regions between water masses or the regions of mixing of the water masses and TokrokA (1959) mentions that the abundant occurrence of this species seems to be seen often in or near the region of mixing between the elegans-water and the warm water in the North Pacific. The water temperature in the regions of mixing of water masses in the North Pacific agrees with that of the distributional range of this species in the above-mentioned surveyed area, and this seems to show that S. minima may occur in the warm water mass when the water temperature is lowered by some causes. The descent of the water temperature in the Kuroshio region is generally caused by the mixing of the coastal water or the cold water mass, besides the seasonal variation of the water temperature itself. And the occurrence of S. minima along Section $\mathrm{G}$ shown in Fig. 9 seems to reflect the latter phenomenon rather than the former.

\section{0) Sagitta elegans}

This species occurred abundantly in samples from the Oyashio region, but its proportion was rather small in the deep water sample. It has never been found in either deep water samples or shallow water ones from the Kuroshio region west of the Ridge.

TChindonova (1955) states that $S$. elegans is an inhabitant of the surface layer, attaining down to $300-400 \mathrm{~m}$ in the KurileKamchatka Trench. This is evidently the species characteristic to the Oyashio, but it was quite missing in the deep water sample collected in the adjoining Kuroshio region east of the Ridge because of its subsurface distribution.

\section{1) Sagitta decipiens}

This is the most important species of the deeper water chaetognaths in the

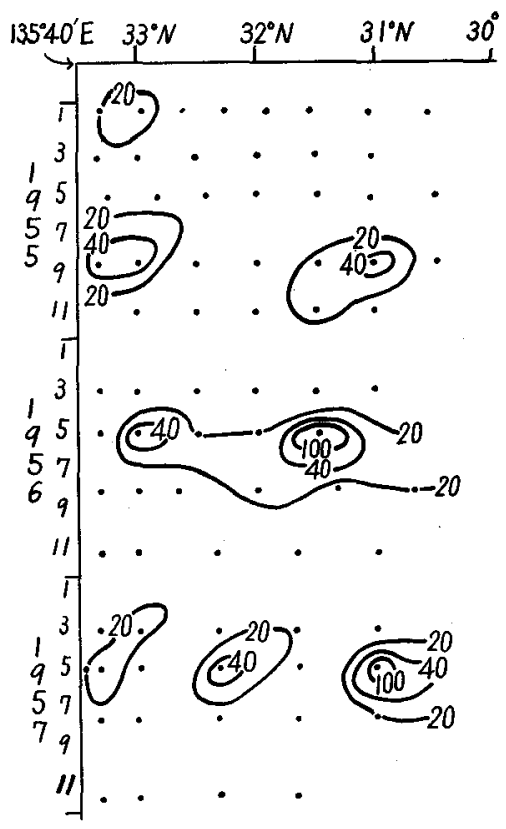

Fig. 9. Individual number of Sagitta minima per $10 \mathrm{~m}^{3}$ along Section $G$ south of the cape of Shionomisaki on the Pacific coast of middle Japan during the period from January, 1955 to November, 1957. 
Kuroshio region and in the far offshore waters beyond the Kuroshio west of the Ridge, though it was not found in the sample collected at the layer deeper than $1000 \mathrm{~m}$. In the eastern Pacific, LEA (1955) reports that S. decipiens was caught in $249 \mathrm{~m}$ and $366 \mathrm{~m}$ hauls made in the open ocean areas off the western coast of Canada. The species seems to be a midwater inhabitant living in the layer of about $100-1000 \mathrm{~m}$ in the Pacific as in other oceans.

\section{2) Sagitta planctonis \& S. macrocephala}

These species are evidently deep-water forms, but they were very few in the present material. In the sample collected in the layer from $1940 \mathrm{~m}$ to $1300 \mathrm{~m}$ at St. U10 in the cold water region west of the Ridge in September, 1954, the whole chaetognath fauna was represented by but a single specimen of S. planctonis (Matsudaira \& Furuhashi, 1955).

\section{3) Eukrohnia hamata}

This species occurred frequently in the deep water samples collected in the Kuroshio region, but the collected individuals were very few there. While, this was the most abundant species in the deeper water sample from the Oyashio region and also in the sample from the Kuroshio region east of the Ridge.

TCHINDONOVA (1955) records the abundant occurrence of E. hamata together with the occurrence of many specimens of $E$. fowleri in the Kurile-Kamchatka Trench and states that the immature forms are very numerous in the surface layer but the small specimens of $E$. hamata decrease with the depth, being replaced by large ones, and finally younger ones disappear completely but sexually mature forms in the deeper layers. In the present material, all specimens were still immature. It seems that E. hamata is distributed in the subsurface water in the Oyashio region, but in the deep layer in the Kuroshio region.

\section{4) Krohnitta subtilis \& $K$. pacifica}

$K$. subtilis was found in the samples from the $510-115 \mathrm{~m}$ layer in the Kuroshio region west of the Ridge and more commonly in the far offshore water samples. $K$. pacifica was found only in the surface water sample in the Kuroshio region west of the Ridge and also in the offshore water samples. $K$. subtilis seemed to be scarce in the surface water of the Kuroshio region but increased in the far offshore water beyond the Kuroshio region west of the Ridge. The vertical distribution of $K$. subtilis in the Kuroshio region west of the Ridge resembles that of Sagitta lyra as is seen in Table 1. Both species seem to inhabit in the deeper water and their rather abundant occurrence in samples from the far offshore waters of lower water temperature and higher chlorinity is to be noted. On the other hand, $K$. pacifica is rather common in the surface water of the Kuroshio region.

The occurrence of Krohnitta spp. including these two species along Section 
$\mathrm{G}$ is shown in Fig. 10 which shows that they occurred in the far offshore water more frequently and abundantly than in the nearshore water, exclusive of the single case in May, 1956 when the stream centre of the Kuroshio approached very near the coast.

\section{5) Pterosagitta draco}

Eleven specimens were found in the surface water samples in the Kuroshio region west of the Ridge and more abundant individuals in the far offshore water samples.

The occurrence of this species along Section $G$ is shown in Fig. 11. This shows that the species occurred more abundantly and frequently in the offshore water than in the inshore water.

\section{Summary and Conclusions}

1. Twenty species of chaetognaths were found in the waters off the southern Pacific coast of middle Japan west of the Ridge. Fifteen of these species seem to be tropical or sub-tropical forms and they were found only in

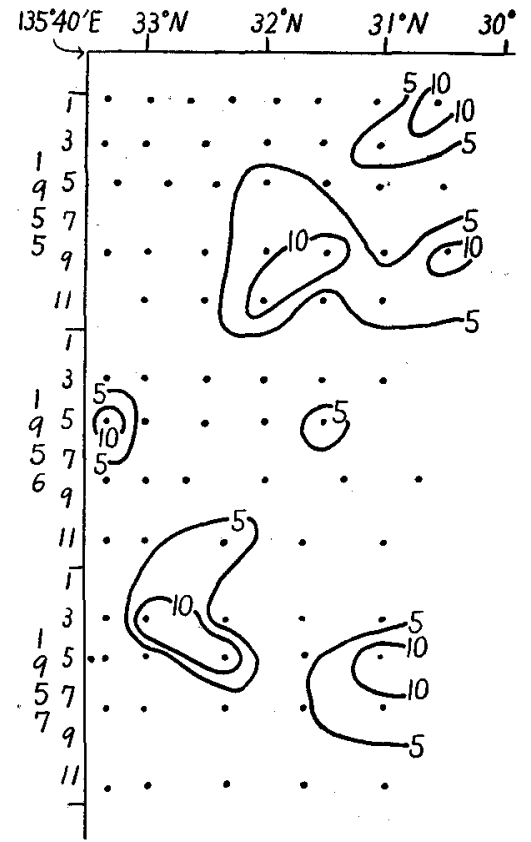

Fig. 10. Individual number of Krohnitta subtilis $+K$. pacifica per $10 \mathrm{~m}^{3}$ along Section $G$ south of the cape of Shionomisaki on the Pacific coast of middle Japan during the period from January, 1955 to November, 1957.

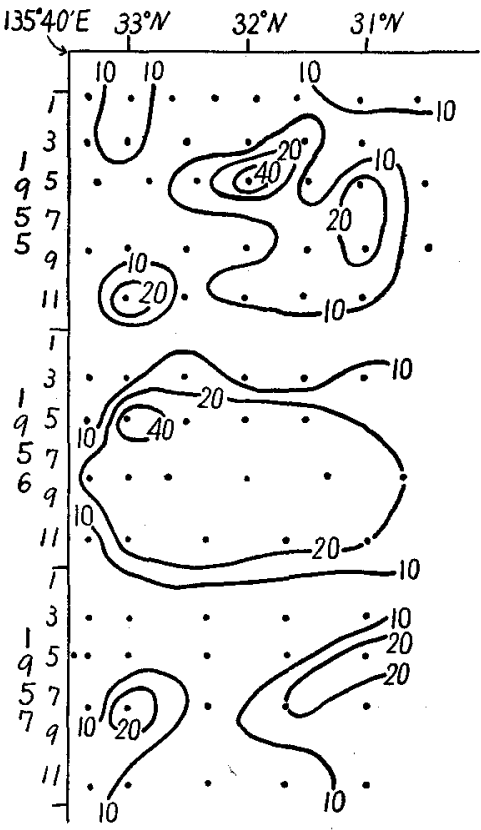

Fig. 11. Individual number of Pterosagitta draco per $10 \mathrm{~m}^{3}$ along Section $G$ south of the cape of Shionomisaki on the Pacific coast of middle Japan during the period from January, 1955 to November, 1957. 
the upper water samples collected in the layers shallower than $760 \mathrm{~m}$. Sagitta bedoti was never found in any deep-water samples, although it was common in the surface water of the cold water region and also in the coastal water. The remaining 4 species are considered to be the abyssal forms; S. decipiens was the commonnest species of all the four in the deep waters west of the Ridge.

2. Seven species of chaetognaths were found in the waters east of the Ridge. Three of these seem to be abyssal forms and Eukrohnia hamata was the most dominant species in the deep waters east of the Ridge. S. elegans characteristic to the Oyashio was found only in the subsurface water samples from the Oyashio region, but never found in either the deeper or upper waters west of the Ridge.

3. The occurrences of chaetognaths along Section $G$ south of the cape of Shionomisaki in the years 1955-'57 were discussed. The seasonal fluctuation was seen clearly in Sagitta enflata, S. regularia and $S$. minima, the first two were common in the season from summer to autumn, while the last one was found commonly in the season when the water temperatures at $50 \mathrm{~m}$ layer was maintained in the range from $20^{\circ} \mathrm{C}$ to $24^{\circ} \mathrm{C}$. The occurrence of Sagitta hexaptera, $S$. lyra, Krohnitta subtilis, K. pacifica and Pterosagitta draco seemed to be much affected by the strength of respective water masses found in the surveyed area. Generally they occurred in the far offshore water samples, but also in the inshore water samples when the stream centre of the Kuroshio approached near the coast. Sagitta bedoti occurred only in the period when the cold water region became large and its westwards extention reached Section $G$ or beyond it.

4. The difference found in the chaetognath fauna between the deep waters west of the Ridge and that east of the Ridge was not so definitive as in the case of copepods shown in the previous paper of the present author (FURUHAsHI, 1961). However, the abundant occurrence of Eukrohnia hamata might be characteristic to the samples from the deep waters east of the Ridge, while the frequent occurrence of Sagitta decipiens, with scarcity of Eukrohnia hamata, might be characteristic to the samples from the deep waters west of the Ridge.

\section{REFERENCES}

BIERI, R. 1959. The distribution of the plankton chaetognatha in the Pacific and their relationship to the water masses. Limnol. Oceanogr., vol. 4, no. 1, pp. 1-28.

FuruhashI, K. 1953. On the vertical distribution of animal plankton in the Sea of Japan off San'in-District in summer of 1952. Publ. Seto Mar. Biol. Lab., vol. 3, no. 1, pp. 61-74. 1958. Notes on Chaetognaths collected from the East China Sea. Umi to Sora, vol. 34, no. 2, pp. 7-10. (In Japanese) 1959. On the pelagic Chaetognatha collected from the Kuroshio warm current region south of Honshu. I. Notes on some chaetognaths as indicator of "Kuroshio" area and cold water region. Ibid., vol. 35 , no. 4 , pp. 81-84.

1961. On the possible segregation found in the copepod fauna in the deep waters off the south-eastern coast of Japan. Publ. Seto Mar. Biol. Lab., vol. 9, no. 1, pp. 1-15. 
LEA, H. E. 1955. The chaetognaths of western Canadian coastal waters. J. Fish. Bd. Canada, vol. 12 , no. 4 , pp. 593-617.

MaRumo, R., KitoU, M. and OHWAdA, M. 1958. Vertical distribution of plankton at $40^{\circ} \mathrm{N}$, $150^{\circ} \mathrm{E}$ in the Oyashio water. Oceanogr. Mag., vol. 10, no. 2, pp. 179-184.

MATSUdAIRA, Y. and FUrUhASHI, K. 1955. Notes on some animal plankton collected from the deep layers of the Pacific waters off southern Japan. Umi to Sora, vol. 31, nos. 5-6, pp. 11-16. (in Japanese)

MORIYASU, S. 1959. Supplementary note on the dynamical property of the cold water region. Oceanogr. Mag., vol. 11, no. 1, pp. 13-19.

Tchindonova, Yu. G. 1955. Chaetognatha of the Kurile-Kamchatka Trench. Trudi Inst. Okeanol., 12, pp. 298-310. (In Russian)

TokIoKA, T. 1940. The chaetognath fauna of the waters of western Japan. Rec. Oceanogr. Wks. Japan, vol. 12, no. 1, pp. 1-22.

1951. Pelagic tunicates and chaetognaths collected during the cruise to the New Yamato Bank in the Sea of Japan. Publ. Seto Mar. Biol. Lab., vol. 2, no. 1, pp. 1-25.

1952. Chaetognaths of the Indo-Pacific. Annot. Zool. Japon., vol. 25,

nos. 1-2, pp. 307-316.

1954 a. Droplets from the plankton net. XIII. Emergence of a dense patch of chaetognaths near the laboratory. Publ. Seto Mar. Biol. Lab., vol. 3, no. 3, pp. 121-122. 1954 b. Ditto. XVI. On a small collection of chaetognaths from the Central Pacific.

Ibid., vol. 4, no. 1, pp. 99-102.

1955 a. On some plankton animals collected by the Syunkotu-Maru in May-June 1954. I. Chaetognatha. Ibid., vol. 4, nos. 2-3, pp. 61-67.

$1955 \mathrm{~b}$. Droplets from the plankton net. XVII. A small collection of chaetognaths and pelagic tunicates from the north-eastern part of the Indian Ocean. Ibid., vol. 5, no. 1, pp. $75-80$.

1956. On chaetognaths and appendicularians collected by Mr. Z. Sagara in the Arafura Sea in May-August 1955. Ibid., vol. 5, no. 2, pp. 71-76.

1957. Chaetognaths collected by the Sōyo-Maru in the years 1934 and 1937-39.

Ibid., vol. 6, no. 2, pp. 13-22.

1959. Observations on the taxonomy and distribution of chetognaths of the North

Pacific. Ibid., vol. 7 , no. 3 , pp. 57-164. 